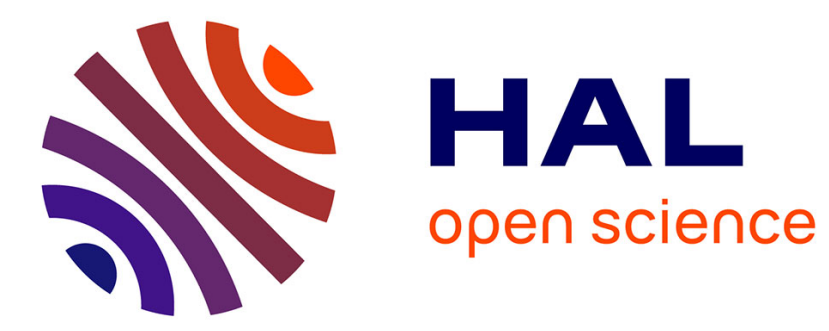

\title{
Being perceptible: Animacy, existentiality and intersubjectivity in constructions with the Finnish verb kuulua 'to be perceptible (through hearing)'
}

Rea Peltola

\section{- To cite this version:}

Rea Peltola. Being perceptible: Animacy, existentiality and intersubjectivity in constructions with the Finnish verb kuulua 'to be perceptible (through hearing)'. Nordic Journal of Linguistics, 2018, 41 (1), pp.39-74. 10.1017/S0332586518000033 . hal-01871494

\section{HAL Id: hal-01871494 \\ https://hal.science/hal-01871494}

Submitted on 19 Nov 2019

HAL is a multi-disciplinary open access archive for the deposit and dissemination of scientific research documents, whether they are published or not. The documents may come from teaching and research institutions in France or abroad, or from public or private research centers.
L'archive ouverte pluridisciplinaire HAL, est destinée au dépôt et à la diffusion de documents scientifiques de niveau recherche, publiés ou non, émanant des établissements d'enseignement et de recherche français ou étrangers, des laboratoires publics ou privés. 
To cite this article:

Peltola, Rea. 2018. Being perceptible: Animacy, existentiality and intersubjectivity in constructions with the Finnish verb kuulua 'to be perceptible (through hearing)'. Nordic Journal of Linguistics 41(1), 39-74. DOI: https://doi.org/10.1017/S0332586518000033

\section{Being perceptible: Animacy, existentiality and intersubjectivity in constructions with the Finnish verb kuulua 'to be perceptible (through hearing)'}

Rea Peltola

Abstract

This paper deals with the grammatical differences and overlaps between the uses of the Finnish kuulua as a verb of auditory perceptibility ('to be audible') and as a verb of appearance, when employed in negative clauses ('to be imperceptible [through unspecified sensory input]'). Both meanings entail perceptibility, existentiality and motion from the experienced towards the experiencer. However, they differ significantly in regard to the nature of the motion as well as the degree of animacy of the subject referent. As a verb of auditory perceptibility, kuulua accepts mainly inanimate subjects referring to a perceivable sound. As a verb of appearance, kuulua is mostly used with animate subjects. The semantic difference between the two constructions is accounted for in terms of objective and intersubjective meaning construal. The potential movement of a sound towards the experiencer concerns the relationship between the world and the subject of conceptualization, whereas the non-appearance of an animate being is viewed on the level of intersubjective cognitive coordination, with regard to interactional expectations. The results of this study shed light on the complex semantics of perceptibility. The analysis is based on 1,528 occurrences of kuulua in dialectal and literary data.

Keywords: animacy, dynamic modality, existentiality, fictive motion, Finnish, intersubjectivity, negation, perceptibility, subjecthood

Rea Peltola, Université de Caen Normandie, CRISCO - EA 4255, Esplanade de la Paix, CS 14032, 14032 CAEN Cedex 5, France

rea.peltola@unicaen.fr 


\section{INTRODUCTION}

\subsection{The objectives of the study}

This paper addresses the semantics of constructions coding the ability to be perceived. The focus is on constructions involving the Finnish verb of phenomenon-based perception kuulua 'to be perceptible (through hearing)'. The subject of these types of verbs codes the stimulus giving rise to a potential perception, while the experiencer of the perception remains implicit (on the types of phenomenon-based perception verbs, see Viberg 2015:99-101). When considering verbs expressing emotional, cognitive, perceptual and bodily experiences in general, the experiencer is inherently an animate, conscious being. The stimulus role, on the other hand, can be occupied by various types of animate or inanimate entities, whose position in regard to the experiential situation can be construed in different ways (Verhoeven 2014:130).

As a verb of perceptibility, kuulua can refer to the potentiality of being heard or to the (in)ability of being perceived through unspecified sensory input. When it comes to auditory perceptibility, kuulua 'to be audible, to sound' (hereafter kuulua $a_{P R C}$ ) leaves the agent of the process implicit and is considered to be incompatible with a human subject (VISK 2004:§1321; von Waldenfels 2012:215) (see ex. 1a, b). In a negative clause, kuulua can code not only inaudibility but also the non-appearance of an entity in a given location: 'to be imperceptible (through unspecified sensory input)' (hereafter, kuulua $a_{A P P}$ ). This latter type of construction has been regarded to be reserved mostly for animate reference (Huumo 2010:9192) (ex. 2). ${ }^{1}$
a. Lapse-n
itku kuulu-u
naapuri-in. 
child-GEN cry KUULUA-3SG neighbour-ILL

'The child's crying can be heard at the neighbours'.'

b. *Lapsi kuulu-u naapuri-in.

child KUULUA-3SG neighbour-ILL

'*The child can be heard at the neighbours'.'2

(2) Las-ta ei kuulu koti-in.

child-PART NEG.3SG KUULUA.CONNEG home-ILL

'The child is not coming home.'

Clauses with kuulua $_{P E R C}$ referring to a quantitatively indefinite entity can be classified as existentials (Huumo 2010:91). ${ }^{3}$ The clause in (3) displays the typical features of Finnish existential sentences. Their word order is AVS, with $A$ being a locative adverbial (in 3, kaikkialta 'from everywhere'). This makes them different from non-existential intransitive clauses, which follow the SVA pattern. In existential clauses, the verb is in the third person singular regardless of the person and number of the syntactic subject, whereas most nonexistential clause types display subject-verb agreement. In positive existential clauses, the subject referring to a countable referent is in the nominative case when in singular form and in the partitive case when in plural (in 3, huuto-j-a 'shout-PL-PART'). The uncountable subject is in the partitive in both the singular (in 3, nauru- $a$ 'laughter-PART', kirkuna- $a$ 'screamingPART') and plural forms. This variation in subject case marking distinguishes existential clauses from other clause types.
(3)
Ja kaikkia-lta
kuulu-i
$\underline{\text { ilois-i-a }}$ huuto-j-a, 
and everywhere-ABL KUULUA-PRET.3SG joyful-PL-PART shout-PL-PART

nauru-a ja kirkuna-a.

laughter-PART and screaming-PART

'You could hear joyful shouts, laughter and screaming coming from everywhere.'

(FLC, finne_1916_kiljusen_herrasvaki_satumaassa:p584)

In negative existentials, the singular subject with countable reference is also in the partitive. In this sense, the clauses with kuulua $_{A P P}$ can likewise be regarded as a type of existential use of kuulua (see ex. 2). ${ }^{4}$

The present paper investigates the grammatical differences and overlaps between the uses of the Finnish verb kuulua as a verb of auditory perceptibility and as a verb of nonappearance and proposes an explanation for the link between the meanings of kuulua and the degree of animacy of the subject referent, existentiality and negation. In so doing, it sheds light on the semantic anatomy of perceptibility and the different types of conceptualization of the relationship between the experiencer and the experienced. It shows that an expression of perceptibility can perform functions both on the level of objective conceptualization, where the construal of the situation by the subject of conceptualization (hereafter, SoC) is profiled, and of intersubjective conceptualization, where the cognitive coordination between SoCs is foregrounded (see Verhagen 2005:16-19). The main outcome of the analysis is that kuulua $_{P E R C}$ codes the SoC's experience of the appearance of an auditory signal, in other words, the relationship between the experiencer and the world, whereas $k u u l u a_{A P P}$ indicates the intersubjective experience of the non-appearance of an interactional (conversational, behavioural) move, that is, the cognitive coordination between SoCs.

The paper is organised as follows. It begins by presenting the data in 1.2 before giving an overall picture of the polysemy and the morphological structure of the verb kuulua in 1.3. 
In Section 2, I introduce the most important semantic and syntactic concepts involved in the study. In 2.1, I discuss linguistic animacy as a gradual category in connection with other prominence scales, such as individuality and agency. I also note the link between animacy and the potential to be part of the cognitive coordination between SoCs. In 2.2, I look at the meaning of perceptibility through the notions of dynamic modality and fictive motion and discuss perceptibility in relation to the general typology of expressions of perception. In 2.3, I consider the grammatical and semantic properties of existential sentences and the dynamics between existentiality and perceptibility. In Section 3, I analyse the syntax and semantics of the kuulua $_{P E R C}$ and $k u u l u a_{A P P}$ constructions in the data according to the degree of subject animacy and with regard to the negative existential meaning. In 3.1, I look at the auditory perceptibility denoted by kUulua $a_{P E R C}$ constructions and the variation between existential and non-existential constructions within KUulua $_{\text {PERC }}$ utterances, and in 3.2, I explore the connection between animacy, the meaning of non-appearance and existential predication. Finally, I discuss the outcomes of the analysis in Section 4 in terms of intersubjective meaning construal.

\subsection{Data}

The data was made up of two parts. One was extracted from the Digital Morphology Archives (hereafter, DMA) comprising spoken dialect data. ${ }^{5}$ The other was drawn from the Corpus of Finnish Literary Classics (FLC) comprising mainly prose and drama but also poetry and aphorisms from the 1880s until the 1930s. The search was carried out in all dialect groups in the DMA and in all literary productions present in the FLC. All occurrences of kuulua $a_{P E R C}$ and kuulua $_{A P P}$ were collected (for the constructions excluded from the data, see Section 1.3). References for the corpora can be found at the end of the paper. The data contained 1,528 
occurrences of kuulua. Table 1 presents the occurrences in the two parts of the data according to the meaning of kuulua.

\begin{tabular}{lrr}
\hline & DMA & FLC \\
\hline kuulua $_{P E R C}$ & 438 & 1000 \\
\hline kuulua $a_{A P P}$ & 32 & 58 \\
\hline TOTAL & $\mathbf{4 7 0}$ & $\mathbf{1 0 5 8}$ \\
\hline
\end{tabular}

\section{Table 1. Occurrences of kuulua.}

The main reasons for selecting these two corpora was their vastness (as occurrences of kuulua $_{A P P}$ were predicted to be of a relatively low frequency) and the possibility of running searches by using the different flexional forms of kuulua as keywords. Using the FLC corpus also allowed me to investigate kuulua in prose dialogues, which make use of the characteristics of everyday conversations (see Nykänen \& Koivisto 2016) and in which participants' expectations are often more or less explicitly presented. Moreover, I was able to analyse long stretches of text and thus take into account the complexity of the contextual factors contributing to the interpretation of kuulua.

While the DMA represents non-standardized variants of Finnish spoken by informants born at the end of the $19^{\text {th }}$ and beginning of the $20^{\text {th }}$ centuries, the FLC reflects language use in the decades when Finnish was in the process of being standardized. The fact that both corpora consist of relatively old language use meant there was a possibility that uses of kUuluaPERC and kUuluaAPP unknown to the contemporary standardized Finnish could occur. However, based on the author's judgment as a native speaker, the occurrences of kuuluaPERC and kuuluaAPP in the two parts of the data displayed no significant differences from contemporary uses of these verbs.

\subsection{The structure and polysemy of kuulua}


Kuиlua (vowel stem kuulu-) is derived, with a general intransitivizing affix - $U$, from the verb kuulla (vowel stem kuule-, consonant stem $k u u l$-), denoting auditory experience ('to hear') (for the system of perception verbs in Finnish, see Huumo 2010:52-54). There are other existential verbs in Finnish constructed with the $U$-affix and entailing an implicit experiencer

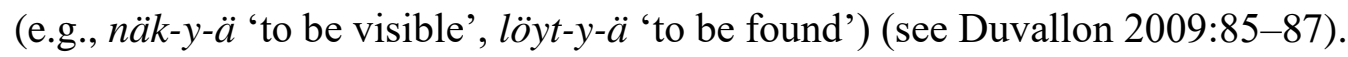

The so-called derivational passive constructions (VISK 2004:\$1344-1346) are also formed with the affix - $U$ (e.g. Puut kaat-u-i-vat 'The trees make.fall-U-PRET-3PL' $>$ 'The trees fell'). The link between perceptibility verbs and the passive voice is explicitly manifested in languages where source-based auditory perception is coded by the passive form derived from the experiencer-based perception verb 'hear'. This is the case in Swedish where all perceptibility verbs are marked with the morphological passive marker, for example, höra$s$ 'hear-PASS' > 'to be audible' (see Viberg 2015:100; for an illustration in Dongolawi, see Jakobi \& El-Guzuuli 2013:207). The link with the passive voice is understandable because expressions of perceptibility background the actual experiencer, code the stimulus as their grammatical subject and entail that the stimulus can potentially be perceived by anyone who should find themselves in the position of the experiencer.

In Finnish, the semantics of derivational passives and kuulua constructions are, however, fundamentally different. Unlike perception, the process coded by a derivational passive entails a change in the state of the subject referent. Moreover, Finnish derivational passives could actually be considered as a type of anticausative constructions (see Huumo 2010:54). They produce a reflexive and automative meaning and do not include an animate participant (either implicitly or explicitly) that is comparable to the experiencer in constructions with kuulua (see Hakulinen 1979:269-271; VISK 2004:§334-336, 1344-1346). 
When used as a verb of perceptibility, kuulua takes either a NP, as in (1)-(3), or a finite complement clause (4) as subject. It can also form a construction with a participial form (5).

(4) Kuulu-u, että he o-vat palan-nee-t. KUULUA-3SG COMP 3PL AUX-3PL return-PST.PTCP-PL ('It can be heard'>) 'I hear they have returned.'

(NS, s. v. kuulua)

\author{
(5) Ovi kuulu-i käy-vän. \\ door KUULUA-PRET.3SG open.and.close-PRS.PTCP \\ 'The door could be heard opening and closing.'
}

(NS, s. v. kuulua)

When associated with a perception verb, complement clauses and non-finite constructions are susceptible to coding meanings other than the actual event or object of perception (see Dik \& Hengeveld 1991, Boye 2010). ${ }^{6}$ A salient example of this is the evidential use of the verb kuulua to mark information as hearsay (as in 4) (VISK 2004: § 1493). ${ }^{7}$ Occurrences of kuulua with a complement clause or a non-finite construction were therefore excluded from the data, in order to focus attention on the so-called immediate perception, as opposed to knowledge acquired.

For the same reason, occurrences of kuulua expressing the impression evoked by the perception, such as comparison ('sound like') or speaker's evaluation ('sound ADJECTIVE', see ex. 6), were also excluded from the data (see Huumo 2010:53). 


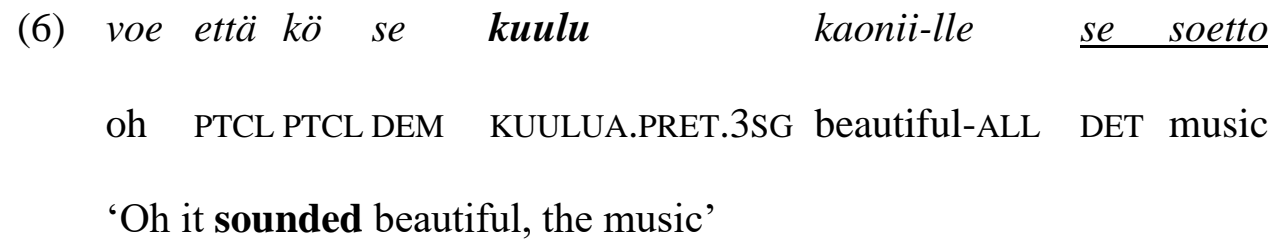

(DMA, Laukaa)

These constructions comprise an allative (ex. 6, kaonii-lle 'beautiful-ALL') or ablative complement. In contemporary standard Finnish, another derived form kuulostaa 'sound (like)' is used in these contexts.

Apart from its uses as a verb of perceptibility, kuulua can convey the meaning 'belonging to someone or something':

(7) Kene-lle nио viljelykse-t kuulu-vat?

Q-ALL DEM.PL plantation-PL KUULUA-3PL

'Who do those crops belong to?'

(NS, s. v. kuulua)

(8) Nämä kappalee-t kuulu-vat yhteen.

DEM.PL piece-PL KUULUA-3PL together

'These pieces belong together.'

(NS, s. v. kuulua)

This is considered to be a relatively recent meaning extension, possibly motivated by the uses of gehören in German and (till)höra in Swedish (Hakulinen 1979:483; Häkkinen 1987; see also Viberg 2008:152-153). As these occurrences of kuulua do not display the meaning of (immediate) perception, they were not included in the data. 


\section{THEORETICAL PREMISES}

\subsection{Animacy, individuality and intersubjectivity}

There is no one-to-one equivalence between the linguistic concept of animacy and the biological meaning of the term that distinguishes entities that are alive from those that are not. Yamamoto (1999) calls this latter animacy as such. Linguistic animacy, or inferred animacy (ibid.), is a gradient category that interacts with other semantic properties and contextual factors (see also Kittilä et al. 2011:5-6).

In the Animacy hierarchy, the highest position is occupied by the most animate entities (the speech act participants) and the lowest by the most inanimate (abstract entities) (see Silverstein 1976; for a discussion, see Yamamoto 1999:24-36; Lockwood \& Macaulay 2012). The order of entities on the animacy scale is based on properties other than the actual degree of 'being alive'. The speech act participants' viewpoint, ranking highest on the scale, is the most accessible to the speaker, whereas the other animate beings (referred to using third person forms) do not necessarily share the same spatiotemporal setting with the interlocutors (see Langacker 1991:307). Following on from this, as emphasized by Langacker (1991:306307) (see 9), the entities ranking high on the animacy scale are more likely to produce an empathic response in the speaker than those ranking low (Kuno \& Kaburaki 1977:653).

(9) $\quad$ speaker $>$ hearer $>$ human $>$ animal $>$ physical object $>$ abstract entity (Langacker 1991:307) 
Animacy also correlates with individuality, that is, the property of being independent of others, directly identifiable and persistent through time (Fraurud 1996; Dahl 2008:147148). Singular entities that we know the most about and which resemble us are most likely to become individuated (see Fraurud 1996:79-80). This also explains the position of abstract entities at the lowest level of the scale. Theoretical, non-material entities are not likely to be conceptualized as individuals.

Dahl's (2008) cognitive scale (see 10) reflects the grammatical animacy hierarchy and takes into account the role of individuation. It places self (the speaker as an individual different from others) as the starting point of the hierarchy that describes the order in which we treat individuals cognitively. It shows the central role played by animacy in our approach to entities other than ourselves but stops short of making further distinctions between different types of animates and inanimates.

(10) self - other animate individuals - inanimate objects

In this paper, the notion of animacy is considered on three fronts. First, the implicit perceiver of a kuulua clause is a being who is capable of receiving an auditory signal and giving meaning to it. Second, animacy is linked with the notions of agency and subjecthood. In contrast to inanimate entities, the most animate beings have the capacity to 'volitionally initiate physical activity' (Langacker 1991:285; see also Van Valin \& Wilkins's typology of agentive properties [1996:314-315]). ${ }^{8}$ In terms of semantic roles, sentience makes animate beings the most typical experiencers. When combined with volition, it also makes them the most typical agents (Dowty 1991:577; Dahl 2008:145; see also Kittilä et al. 2011:11-13) and, on a syntactic level, the most typical subject referents (Dahl \& Fraurud 1996). The different 
types of perception verbs are characterized by different degrees of animacy and agency of the participants (see Section 2.2).

Third, animacy, sentience and agency are the attributes of beings included in the intersubjective community that makes interaction and the sharing of experiences possible (see, e.g., Zlatev et al. 2008). The positions occupied by animate beings in situations are such that they allow the speaker to adopt the viewpoint of the other being (see the discussion on empathy above) and therefore provide certain expectations as to what might be the next adequate discursive move at each stage within the interaction (Verhagen 2008:327). ${ }^{9}$ In this paper, intersubjectivity is considered as a dimension of linguistic meaning, where two SoCs enter into this kind of relationship of cognitive coordination (Verhagen 2005, 2008). Some linguistic constructions foreground the intersubjective dimension, i. e. the participants (the 'other minds') and the immediate context of the communicative event (Figure 1), while others profile the object of conceptualization, e. g. in a situation of labeling objects (Figure 2) (see Verhagen 2005:6, 16-18). ${ }^{10}$ The differences in profiling between intersubjective and objective poles are gradual and can be conceived of as forming a continuum. ${ }^{11}$

Object of conceptualization:

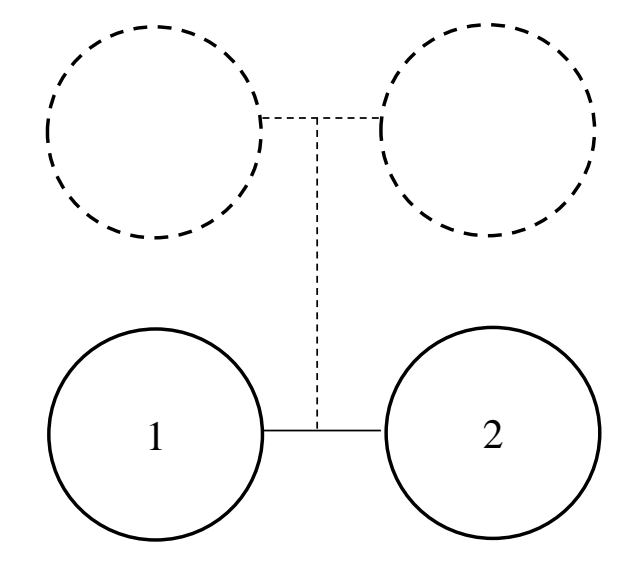

Subject of conceptualization:

Figure 1. Construal of the intersubjective dimension of conceptualization. 
Object of conceptualization:

Subject of conceptualization:

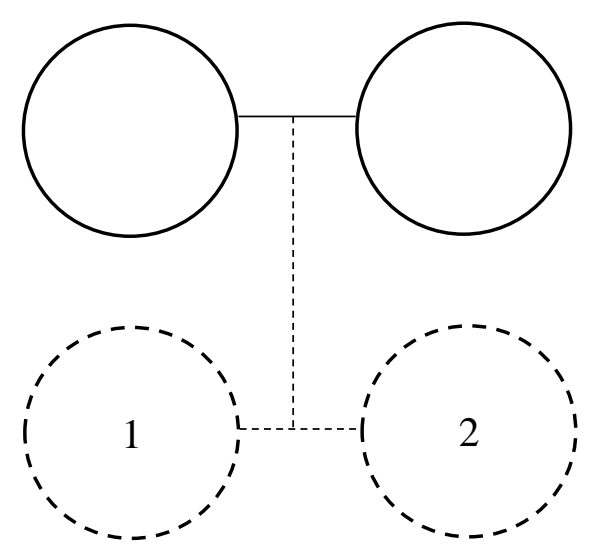

Figure 2. Construal of the object of conceptualization.

It seemed essential to take the intersubjective dimension into account when distinguishing the meanings of $k u u l u a_{P E R C}$ and $k u u l u a_{A P P}$. In this analysis, the intersubjective relationship does not just involve the speaker and the interlocutor but also, on another level, the perceiver and the subject referent in the situation of appearance. As for objective conceptualization, the term does not appear in this paper with reference to 'pure cases' of objectivity, such as labeling objects (see Verhagen 2005: 16-17) but to situations where the relationship between the SoC and the object of conceptualization is profiled, instead of the relationship between SoCs.

\subsection{Perceptibility in the typology of expressions of perception}

The verb kuulua can be included in the heterogeneous category of lexical perception verbs, which, from a typological perspective, do not really form a sharply defined class (Aikhenvald \& Storch 2013a). In contemporary Finnish, perception verbs can, however, be organized following Viberg's (1984, 2015) classical paradigm. Each sense modality (sight, hearing, touch, taste and smell) is covered by three basic verbs of perception, and these verbs can be further arranged according to the type of event they denote: 1) transitive verbs coding activity 
controlled by an agent, 2) transitive verbs coding uncontrolled experience and 3) intransitive verbs coding perceptibility. ${ }^{12}$ Verbs belonging to the first two subcategories are considered to be experiencer-based, as they take the experiencer of the perception as their subject. The third type of verbs is source-based, as their subject refers to the entity perceived. For example, in the field of audition, the corresponding verbs in Finnish are 1) kuunnella 'to listen', 2) kuulla 'to hear' and 3) kuulua 'to be audible'. ${ }^{13}$

In Viberg's system, the different types of perception verbs are distinguished by the degree of animacy and agency of their subject. The activity verbs and the experience verbs can take the referents that rank highest on the animacy scale as their subject, whereas the perceptibility verbs cannot, for example, 1) minä kuuntelen 'I listen' and 2) minä kuulen 'I hear' but 3) *minä kuulun 'I am audible'. ${ }^{14}$ When looking at languages in general, however, it becomes clear that the degree of control and, accordingly, the degree of animacy are sensitive to the meaning that emerges from the construction in which the perception verb is used (see Aikhenvald \& Storch 2013b:19-20). ${ }^{15}$ This dynamics is of interest in the present study as we observe two different types of kuulua constructions.

In perceptibility verbs, the experiencer is implicit and generic since the stimulus can potentially be perceived by anyone in the given situation (Huumo 2010:55). As with the experiencer coded by the subject of the experiencer-based verbs, the implicit experiencer in constructions with perceptibility verbs is also an animate entity capable of sensory perception. When it comes to agency, the fact that the experiencer is not coded by the subject reflects the feeble degree of control exercised by the experiencer over the situation (Schneider-Blum \& Dimmendaal 2013:235). The status of the experiencer is further weakened by the physiological particularities of the auditory process. Hearing does not depend on the physical activity of the perceiver to the same extent as seeing (cf. moving and closing one's eyes). Furthermore, 'being audible' entails producing a sound signal, whereas 'being visible' is the 
result of being present in the perceiver's field of view. In this sense, an auditory signal is more autonomous of the perceiving experiencer than a visual signal (see Enghels 2007:28-32; Huumo 2010:87-88). ${ }^{16}$

In kuulua constructions, the presence of an animate experiencer is connected to the capacity to perceive. Perceptibility verbs do not refer to actualized processes or perceptions but to the ability of the stimulus to potentially be perceived. They thus imply the position of the experiencer in regard to the perception, namely their ability to potentially perceive the stimulus. Semantically, perceptibility thus belongs to the domain of dynamic modality, which covers meanings of personal capacity, ability and need as well as possibilities and constraints caused by the circumstances (see, e.g., Palmer 2001). In a sense, dynamic modality is present in all expressions of perception, as they entail an experiencer or an agent capable of perceiving plus, in constructions coding uncontrolled processes, circumstances that allow for the perception to take place, for example, I hear your voice 'I can hear your voice'. In kuulua clauses, due to the generic experiencer, the modal meaning is set to the fore since the signal can be perceived in the given situation by anyone with the ability to perceive. In some languages, perceptibility is in fact coded by experiencer-based perception verbs that are associated with a potential marker (see, e. g., Schneider-Blum \& Dimmendaal 2013:231).

In expressions of perception, the relationship between the perceived entity and the experiencer can be conceptualized as directional in the sense that there is a fictive motion of a signal between the two in one direction or the other (Talmy 2000:115-116). On the one hand, perception can represent a situation of the 'Experienced as Source' type, where the experienced entity sends out a signal towards the experiencer. On the other, the experiencer can be conceived of as the instigator of the process who emits 'a probe that moves from the Experiencer to the Experienced and detects it upon encounter with it' (ibid. 115). This sensory path is of the 'Experiencer as Source' type. 
In Finnish, fictive motion is coded by the system of directional and static locative marking associated with the spatial position of the stimulus or the experiencer. Huumo (2010) noted that the processes described by clauses with the verb kuulua are conceptualized as following a sensory path of the 'Experienced as Source' type. In other words, the audible signal moves from the perceivable entity towards the unspecific, potential experiencer. In examples (11) and (12), this path is viewed from two different viewpoints:

(11) naveto-sta kuulu-u niin aika kolina,
cowshed-ELA KUULUA-3SG PTCL quite.some clatter
'quite a clatter is coming from the cowshed.'

(DMA, Loimaa)

(12) kukko ruppe varha laala-ma rooster start.3SG early sing-INF.ILL 'the rooster starts to crow early' ja se kuulu vähän kaua-s. and DEM KUULUA.3SG quite far.away-LAT 'and it can be heard quite far away.'

(DMA, Mietoinen)

In terms of the conceptual structuring of language, the two examples represent different ways of distributing attention. In (11), the window of attention is placed on the initial part of the path describing the motion of the sound. The elative case ('from') marks the point of origin of the signal, that is, the spatial location of the animals emitting the sound. In (12), the 
conceptual endpoint of the sensory path is foregrounded, as the locative adverb kaua-s ('farLAT') codes the location where the experiencer is situated (see Talmy 2000:Chapter 4).

\subsection{Existentiality and its perception}

From a typological perspective, existential predication has been defined as an alternative way of encoding prototypical figure-ground relationships (The dog is under the tree vs. There is a

dog [under the tree]) (Creissels 2014). In an existential predication, the figure (the existential $\mathrm{S}$-argument) does not represent the central point from which the situation is viewed. The ground (the location of the entity) is taken as the perspectival centre and, in view of the information structure, most often as the default topic (see Huumo 2003:463; Partee \& Borschev 2004; Creissels ibid.). In line with cross-linguistic perspectival analysis, Huumo (2003) has argued that Finnish existential sentences produce a holistic view over the event and downgrade the individual activities involved in the situation. ${ }^{17}$

In terms of analyzing the existential meaning in constructions with kuulua, it is important to note that existential predication does not necessarily involve actual existence but rather the presence of an entity at a location (see the discussion and etymology of the verb exist in Creissels 2014). The same can also be said for negative existentials. According to Veselinova (2013), negative existentials form a functional domain of their own crosslinguistically, which is in interaction with but grammatically and conceptually separate from the domains of existence and negation. In semantics terms, existential predications display special strategies for negation that make it possible to distinguish between absolute negation (non-existence) and relative negation (non-presence).

In what follows, kuulua ${ }_{P E R C}$ and kuulua $_{A P P}$ will appear to vary in the way they code the non-existence and non-presence of an entity. This is due to the fact that, even in existential 
constructions, verbs of perceptibility encode first and foremost the (in)ability to perceive. The localization coincides with the perspective of the experiencer and the situation is viewed with regard to the experiencer's expectations. The meaning of (non-)existence is then inferred from the presence or absence of the stimulus. What is perceived exists - it becomes existent to the experiencer through perception - but what is not perceived may or may not exist.

\section{FROM THE MOVEMENT OF A SOUND TO AN UNEXPECTED PHYSICAL AND INTERACTIONAL ABSENCE}

\subsection{Perceptible auditory signals}

The first part of this analysis concerns subject selection and the negative existential use of kuulua when the verb refers to auditory perception. Syntactically, in constructions with

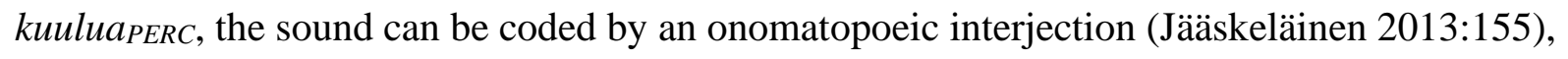
as in (13), or a sequence of direct speech, as in (14) (VISK 2004:§1478).

(13) $[\ldots]$ äkkiä kuulu-i ovikello-n tuttu 'dinderling'! suddenly KUULUA-PRET.3SG doorbell-GEN familiar ONOM '[...] suddenly, the familiar "dingaling" of the doorbell rang.'

(FLC, jarnefelt_vanh:p53)
(14) $[\ldots]$ ja kohta alko-i
kuulu-a: $\quad$ kasaka-t tule-vat!
and soon start-PRET.3SG KUULUA-INF cossack-PL come-3PL '[...] and soon "the Cossacks are coming!" could be heard.'

(FLC, jarnefelt_veneoja:p1993) 
Most constructions, however, include a subject NP that does not present the stimulus as if it was reproduced in its exact, original form, through imitation and other forms of direct quotation, but instead describes the nature or source of the sound. I will now move on to analysing the semantics of the kuulua $a_{P E R C}$ subject NPs. ${ }^{18}$

\subsubsection{The degree of animacy of the subject referent in kuulua ${ }_{P E R C}$ constructions}

Tables $2 \mathrm{a}$ and $2 \mathrm{~b}$ show the distributions of subject constituents of kuulua $a_{P E R C}$ according to their reference in the two parts of the data. The subject referents have been divided into two main categories, namely animate and inanimate referents. Due to the high number of occurrences of the inanimate subject NPs, they have been further separated into five subcategories:

- NPs and demonstrative pronouns referring to sounds

- NPs and demonstrative pronouns referring to events

- NPs and demonstrative pronouns referring to other inanimate entities (objects, mental states)

- indefinite/interrogative ${ }^{19}$ pronouns

- other quantifying pronouns

The category of unclear cases includes kuulua utterances in which it is difficult to determine the referent of the subject. This is mostly due to the fact that there is only a reduced amount of context available in the DMA corpus. In some cases, there is ambiguity between reference to a sound and reference to an event producing the sound.

\begin{tabular}{lrr}
\hline \multicolumn{3}{c}{ DMA } \\
\\
\hline Referent & Occurrences & $\%$ \\
\hline Animate & $\mathbf{1}$ & $\mathbf{0 . 2}$ \\
\hline
\end{tabular}




\begin{tabular}{lrr}
\hline Inanimate & $\mathbf{4 1 0}$ & $\mathbf{9 3 . 6}$ \\
Sounds & 349 & 79.7 \\
Events & 21 & 4.8 \\
Other inanimate entities & 24 & 5.5 \\
Indefinite/interrogative & 5 & 1.1 \\
Otherwise quantified & 11 & 2.5 \\
\hline Unclear & $\mathbf{2 7}$ & $\mathbf{6 . 2}$ \\
\hline TOTAL & $\mathbf{4 3 8}$ & $\mathbf{1 0 0}$
\end{tabular}

Table 2a. The subject referents of kuuluaPERC in the dialect data.

\begin{tabular}{lrr}
\hline \multicolumn{2}{c}{ FLC } & \\
\hline Referent & Occurrences & $\%$ \\
\hline Animate & $\mathbf{4}$ & $\mathbf{0 . 4}$ \\
\hline Inanimate & $\mathbf{9 8 6}$ & $\mathbf{9 8 . 6}$ \\
Sounds & 850 & 85.0 \\
Events & 85 & 8.5 \\
Other inanimate entities & 22 & 2.2 \\
Indefinite/interrogative & 1 & 0.1 \\
Otherwise quantified & 28 & 2.8 \\
\hline Unclear & $\mathbf{1 0}$ & $\mathbf{1}$ \\
\hline TOTAL & $\mathbf{1 0 0 0}$ & $\mathbf{1 0 0}$
\end{tabular}

Table $2 \mathrm{~b}$. The subject referents of kuulua ${ }_{P E R C}$ in the literary data.

In both parts of the data, the majority of the subjects of kuulua ${ }_{P E R C}$ refer to the sound emitted. These subjects are NPs derived from a descriptive verb specifying the quality of the signal, as in (15), or simply coding an unspecified auditory production, as in (16).
(15) $\boldsymbol{e i}$
kuko-n
kievunta kuulu
ennää
NEG.3SG rooster-GEN crowing KUULUA.CONNEG anymore
'rooster crowing cannot be heard anymore'

(DMA, Uukuniemi)

(16) mee mukulat juastiin aina kun

'we, the kids, used to run whenever' 


$\begin{array}{lccc}\text { auto- } n & \underline{\text { ääne-t}} & \text { alko } & \text { kuulu-a. } \\ \text { car-GEN } & \text { sound-PL } & \text { start.PRET.3SG } & \text { KUULUA-INF } \\ \text { 'the sound of a car became audible' } & \end{array}$

(DMA, Tuulos)

The source of the sound is most often expressed by a genitive modifier referring to an animate being (15) or an inanimate entity (16).

The category Event includes subject NPs formed with a deverbal noun, whose lexical meaning does not foreground a sound but an action (17), as well as subjects referring to a proposition (18).

(17) Vähä-n aja-n perästä alko-i kuulu-a

little-GEN time-GEN after start-PRET.3SG KUULUA-INF

'After a while, you could hear'

pöyt-i-en liikuttelu-a [...].

table-PL-GEN displacement-PART

'(the displacement of tables $>$ ) someone moving tables $[\ldots]$ '

(FLC, jarnefelt_vanh:p1202)

(18) aina tietie koska Aino ol liikkeel,

'you always know when Aino is moving around,'

se kuulu-u puhie-st

DEM KUULUA-3SG talk-ELA

'(it can be heard from the talking >) you can hear it from the talking'

(DMA, Asikkala) 
The quantifying pronoun in kuulua $a_{P E R C}$ clauses is mostly the negative polarity pronoun mitään (19), but universal quantification in a positive context is also possible (20).

(19) hevoset seisovat siälä mettäsä niin hiljaa

'the horses stood so still in the forest'

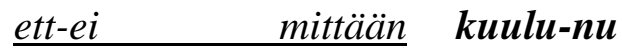

COMP-NEG.3SG anything KUULUA-PST.PTCP

'that nothing could be heard'

(DMA, Loimaa)

(20) Myös varoi hän mitään sanomasta, sillä hänen ominaisuuksiansa oli [...],

'She also restrained herself from saying anything, for it was typical of her [...],'

että kaikki kuulu-i häne-n ääne-stä-än.

COMP everything KUULUA-PRET.3SG 3SG-GEN voice-ELA-POSS.3

'that everything could be heard in her voice.'

(FLC, jarnefelt_vanh:p1040)

As for indefinite and interrogative pronouns as subject NPs, it is important to note that all occurrences are partitive forms of the pronouns jokin (indefinite) and mikä (interrogative), which in principle entail a non-human referent (see VISK 2004: §713), as in (21) and (22).

(21)

kyllä sie-ltä silla alta jotaki kuulu

PTCL DET-ABL bridge.GEN under.ABL something.PART KUULUA.PRET.3SG

'you definitely could hear something from under the bridge' 
(DMA, Saarijärvi)

(22)

\begin{tabular}{|c|c|c|}
\hline vaiti $\underline{m i-t a ̈}$ & sie-ltä (miehen suusta) nyk & kuulu-u! \\
\hline be.IMP.2SG-CLT quiet Q-PART & there-ABL & KUULUA-3SG \\
\hline
\end{tabular}

(DMA, Kalajoki)

As regards the subject nouns referring to inanimate entities other than a sound or an event, it is possible for kuulua $a_{P E R}$ to appear with an abstract noun denoting an emotional state that is likely to give rise to an audible expression, as in (23).

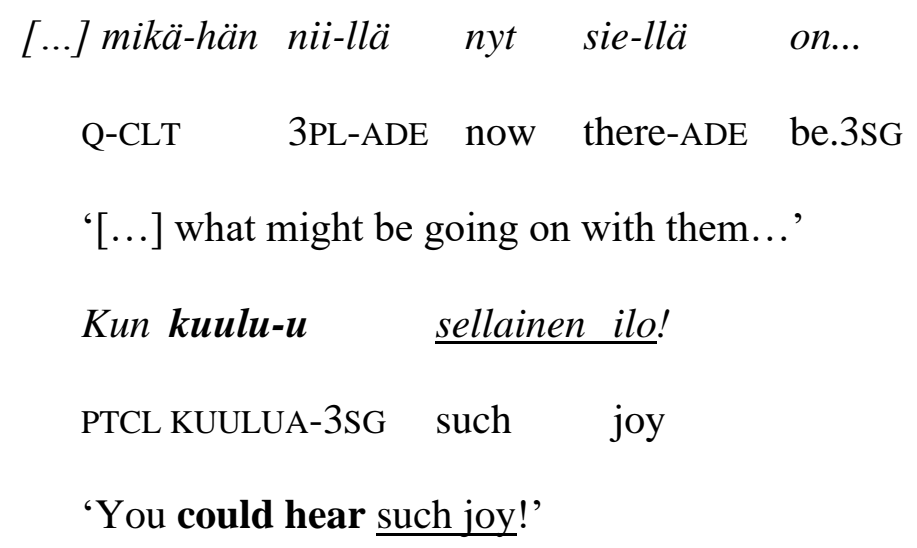

(FLC, lehtonen_putkino:p654)

In most cases, however, these nouns refer to concrete objects, whose most central function is to produce a sound, such as different types of bells (24) and instruments (25) as well as devices used for receiving signals in order to produce sounds (26). Natural phenomena perceived primarily through audition is also possible (27). 
(24) kuuntel-i-m mi-tä ilima-a lehemä-n-kello kuulu-u

listen-PRET-1SG Q-PART air-PART cow-GEN-bell KUULUA-3SG

'I listened to hear which direction the cowbell was coming from

(DMA, Himanka)

(25) vaam minä kävin niillev (posetiivareille) viiskymmentä penniä miehee antamasa

'I went and gave them (the street organ players) fifty pence each'

niin silloo alako peli-k kuulu-a.

PTCL then start.PRET.3SG instrument-PL KUULUA-INF

'and that's when you could hear the instruments'

(DMA, Paavola)

(26) Tilta sano

luul-lee-ser ${ }^{20} \quad$ ratijo-k se kuulu

PROP SAy.PRET.3SG think-PST.PTCP-POSS.3 radio-Q DEM KUULUA.PRET.3SG

(kun toiset lauloivat oven takana).

'Tilta said she thought it was the radio that could be heard (when the others were singing behind the door)'

(DMA, Savitaipale)

(27) ukkone, kuulu jäise-lle

thunder KUULUA.PRET.3SG icy-ALL

'The thunder could be heard on the ice'

(DMA, Ähtäri) 
In the literary data, there were some occurrences of kuulua ${ }_{P E R C}$ subjects where the referent was an inanimate natural element a priori perceivable through vision. In (28) and (29), the subject referent entails continuous movement of water. This type of visual signal is expected to be associated with a sound. In (29), perception through vision only (i.e., excluding audition) is explicitly stated.

(28) Kuulu-i

vain sade-tta ja juoksu-vede-n lirinä-ä.

KUULUA-PRET.3SG only rain-PART and running-water-GEN purling-PART 'You could only hear rain and the purling of running water.'

(FLC, jarnefelt_greeta:p290)

(29) [...] ( saunan lasista) epätodellinen kellanvihreä näköala '[...] (through the window of the sauna) an unreal greenish yellow view' pitkin koske-a, joka ei kuulu, ainoastaan näky-y [...]. along rapid-PART REL NEG.3SG KUULUA.CONNEG only be.visible-3SG 'along the rapids, which could not be heard, only seen [...].'

(FLC, aho_kalalastut:p726)

There were only five occurrences of animate subject referents in kuulua $a_{P E R}$ constructions in the data, and these involved not just humans but other animate beings too (cf. VISK 2004:\$1321; von Waldenfels 2012:215). ${ }^{21}$ Because of the small number of occurrences, no generalizations can be made on the conditions that permit the animate subject to appear. The subject NP presented in example (30), however, gives an idea of the semantic factors that could come into play when an animate entity exceptionally takes the position of the stimulus. 
(30) Kuta keskemmä kirkkoa hän etenee, sitä suuremmaksi kasvaa melu.

'The further he advances in the church, the louder the noise grows.'

Soitta-va orkesteri ylhä̈̈-ltä lehteri-ltä ei kuulu

play-PRS.PTCP orchestra up-ABL balcony-ABL NEG.3SG KUULUA.CONNEG

mihinkään se-n rinnalla.

anywhere DEM-GEN beside

'In comparison, the orchestra playing on the balcony cannot be heard at all.'

(FLC, aho_minka_mitakin_italiasta:p111)

The subject NP refers to a human collective whose primary function is to produce a sound. Furthermore, the subject referent is a relatively unagentive entity, since an individual's control over the situation is remarkably reduced. Based on the author's intuition as a native speaker, the clause would not be acceptable with a subject NP referring to an individual animate being (e. g. lapsi 'child') whose function is not primarily to produce a sound.

In this section, the data have shown that the subject NP of kuulua $P E R C$, in the rare cases where it does not directly refer to a sound, denotes an inanimate abstract or concrete entity or, very marginally, an animate collective entity, whose inherent property is to produce a sound. This observation is in line with Enghels' (2007:29-30, 133-135) description of the particularities of auditory perception: to hear is to perceive the event of something or someone producing a sound signal, not to perceive the object or the animate being as such (cf. visual perception). Utterances with kuuluaPERC code the potential movement of the sound towards the experiencer.

\subsubsection{Variation between existential and non-existential predication in negative kuulua PERC} constructions 
In principle, negative kuulua $a_{P R C}$ constructions allow us to differentiate between prototypical existential predication, where the subject is in the partitive case, and non-existential predication, where the subject is in the nominative. In the case of prototypical existential predication, the viewpoint is on the location, and the non-presence of the subject referent in that location is foregrounded with no suggestion as to whether this non-presence is absolute non-existence of a non-specific entity or relative non-presence of a specific existent entity. In the case of non-existential predication, the existential presupposition is maintained. The entity is viewed as being absent in a given location, but its existence, for example, in another location, is not denied (see Huumo \& Lindström 2014). Examples (31), including a partitive subject, and (32), including a nominative subject, illustrate this:

(31) Takanani on suuri luostari, niinkuin autio linnoitus,

'There was a big abbey behind me, like an abandoned fortress,'

jo-sta ei kuulu hiiskahdus-ta-kaan.

REL-ELA NEG.3SG KUULUA.CONNEG Sound-PART-CLT

'from which not a sound could be heard.'

(FLC, aho_minka_mitakin_italiasta:p161)

(32) Vaan huuto-nsa

ei kuulu-nut

mihinkään kaivo-sta [...].

but scream.NOM-POSS.3 NEG.3SG KUULUA-PST.PTCP anywhere well-ELA

'But her scream from the well could not be heard anywhere [...].'

(FLC, pakkala_elsa:p846) 
In (31), the existential clause does not tell us whether there has been a sound emitted in the fortress as such. In contrast, the clause in (32) implies the scream has taken place (regardless of the presence or absence of the possessive suffix, which, as such, produces a specific reading). Only its perception is denied.

Occurrences of the nominative subject in negative kuulua $a_{P E R C}$ utterances are, however, relatively rare in the data. Table 3 shows the distribution of subject NPs of positive and negative kuulua ${ }_{P E R C}$ utterances according to case. The category 'Other' includes, primarily, unclear cases but also some genitive forms motivated by the use of modal verbs or infinitive conjugation.

\begin{tabular}{l|rrrr|rrrr}
\hline & \multicolumn{4}{|c|}{ Positive } & \multicolumn{4}{c}{ Negative } \\
\hline & NOM & PART & Other & Total & NOM & PART & Other & Total \\
\hline DMA & 281 & 87 & 22 & 390 & 7 & 36 & 5 & 48 \\
$\%^{\mathrm{a}}$ & 64.2 & 19.9 & 5.0 & 89.0 & 1.6 & 8.2 & 1.1 & 11.0 \\
$\%^{\mathrm{b}}$ & 72.1 & 22.3 & 5.6 & 100.0 & 14.6 & 75.0 & 10.4 & 100.0 \\
\hline FLC & 474 & 312 & 59 & 845 & 28 & 124 & 3 & 155 \\
$\%^{\mathrm{a}}$ & 47.4 & 31.2 & 5.9 & 84.5 & 2.8 & 12.4 & 0.3 & 15.5 \\
$\%^{\mathrm{b}}$ & 56.1 & 36.9 & 7.0 & 100.0 & 18.1 & 80.0 & 1.9 & 100.0 \\
\hline
\end{tabular}

${ }^{a}$ The proportion of all kuulua PERC occurrences in the data

b The proportion of positive/negative kuulua $a_{P E R C}$ occurrences in the data

Table 3. Subject case marking in kuulua ${ }_{P E R C}$ utterances.

The frequency of the partitive case in negative kuulua $a_{P E R C}$ utterances is remarkably high in both parts of the data. In the DMA data, $75 \%$ of negative kuulua PERC utterances take a partitive subject, as compared with $16 \%$ that take a nominative subject. In the FLC data, $80 \%$ of negative kuulua PERC utterances have a partitive subject and $18 \%$ a nominative subject.

It also appears from the data that a nominative subject does not necessarily refer to an existent unperceived sound. It can also occur in a context where the sound is absolutely nonexistent, as in (33). 
(33) Sitten nukutaan Putkinotkon kesäisellä pihalla. Siellä on hiljaista, nurmikolla ja kallioilla, kerrankin. Ei kuulu huutoja eikä itkua, ei kirkunaa, ei rinnanpohjasta tulevia ja etäälle kantavia toitotuksia. Ei laulua, ei rallatusta, ei putkien soittoa, ei räkätystä. Ei $\underline{\text { lehmien ja pässien äänten matkimista tai karjan kotiin huutamista, vingutusta, karhun tai }}$ koiran äänten jäljittelyä, peltisten onkimato-purkkien rämistelyä vastatusten, niin että vuori pihan toisessa kupeessa räikkyisi. Ei kuulu koiran haukunta, sillä Hurjakin makaa portaittensa alla, josta sen valkea pää näkyy, tavoitellen silloin tällöin kärpäsiä.

(lehtonen_putkino:p1762)

'Then everyone sleeps in the summery yard of Putkinotko. There is silence on the lawn and on the rocks for once. [cannot be heard >] You cannot hear shouts-PART nor $\underline{\text { crying-PART, no screaming-PART, no hollering-PART coming deep from the chest and }}$ $\underline{\text { reaching far. No singing-PART, no trolling-PART, no playing-PART pipes, no chattering- }}$ PART. No imitation-PART of the sounds of cows and rams or calling-PART the cattle back home, fiddling-PART, reproducing -PART the sounds of a bear or a dog, tin cans of fishing worms rattling-PART together, so that the hill across the yard resonates. [Cannot be heard >] You cannot hear the dog barking-NOM, for even Hurja is lying under the stairs, showing his white head, reaching for a fly every now and then.'

In this extract, I have underlined all the subject NPs of the two negative kuuluaPERC utterances. Apart from koiran haukunta 'dog's barking', the subject NP of the second utterance, they are all in partitive case (see the marking PART). Both kuulua $a_{P E R C}$ utterances, however, encode absolute non-existence. The latter utterance is not about not being able to hear while the dog is barking but about the dog not emitting a sound, since the animal is described as being otherwise engaged. The reason for the use of the nominative here is likely 
to be the degree of specificity of the entity not emitting the sound. The description of the nonaudible sounds moves from a general to a more specific level with the NP koiran haukunta 'dog's barking'. There is no genitive modifier coding an animate source for the other sounds. The barking is the only sound that is associated with a spatiotemporal reference point, concretized in the actual living being, while the other sounds are only viewed from the point of view of the state of affairs 'not being audible' (on the subject case selection and the individuation of the referent in Finnish, see Duvallon, forthcoming). The transition is also reflected by the fact that the verb ei kuulu 'cannot be heard' is reiterated at this stage.

\subsection{The non-appearance of a physical and interactional movement}

\subsubsection{The degree of animacy of the subject referent in kuulua ${ }_{A P P}$ constructions}

The second part of the analysis concerned the use of kuulua as a verb of appearance. This category contain verbs that describe the becoming-perceptible of an entity. Levin (1993:258259) included in this category verbs whose meaning of appearance results from an extended, figurative use. This is also likely to be the case for kuulua (see Section 4).

Tables $4 \mathrm{a}$ and $4 \mathrm{~b}$ show the distribution of the subject NPs of kuulua $a_{A P P}$ according to the nature of the referent in the two parts of the data.

\begin{tabular}{lrr}
\hline \multicolumn{3}{c}{ DMA } \\
\\
\hline Referent & Occurrences & $\%$ \\
\hline Animate & $\mathbf{2 5}$ & $\mathbf{7 8 . 1}$ \\
\hline
\end{tabular}




\begin{tabular}{lrr}
\hline Inanimate & $\mathbf{2}$ & $\mathbf{6 . 3}$ \\
Sounds & 0 & 0 \\
Events & 0 & 0 \\
Other inanimate entities & 1 & 3.1 \\
Indefinite/interrogative & 0 & 0 \\
Otherwise quantified & 1 & 3.1 \\
\hline Unclear & $\mathbf{5}$ & $\mathbf{1 5 . 6}$ \\
\hline TOTAL & $\mathbf{3 2}$ & $\mathbf{1 0 0 . 0}$ \\
\hline
\end{tabular}

Table 4a. The subject referents of kuulua $_{A P P}$ in the dialect data.

\begin{tabular}{lrr}
\hline \multicolumn{1}{c}{ FLC } & & \\
\hline Referent & Occurrences & $\%$ \\
\hline Animate & $\mathbf{4 2}$ & $\mathbf{7 2 . 4}$ \\
\hline Inanimate & $\mathbf{1 6}$ & $\mathbf{2 7 . 6}$ \\
Sounds & 0 & 0 \\
Events & 1 & 1.7 \\
Other inanimate entities & 10 & 0 \\
Indefinite/interrogative & 0 & 0 \\
Otherwise quantified & 5 & 8.6 \\
\hline Unclear & $\mathbf{0}$ & $\mathbf{0}$ \\
\hline TOTAL & $\mathbf{5 8}$ & $\mathbf{1 0 0 . 0}$
\end{tabular}

Table 4b. The subject referents of kuulua $_{A P P}$ in the literary data.

The occurrences of $k u u l u a_{A P P}$ are considerably less frequent in the data than those of kuulua $_{P E R C}$ (cf. Tables $2 \mathrm{a}$ and $2 \mathrm{~b}$ ). This is probably due to the fact that $k u u l u a_{A P P}$ is used only in a very particular situation, whereas kuulua $_{P E R C}$ denotes one of the basic sensory-perceptual processes.

As expected, the two uses of kuulua are not alike in terms of subject reference. The kuulua $_{A P P}$ occurrences support Huumo's (2010:91-92) view, which states that there is a strong tendency for animate subjects to occur with $k u u l u a_{A P P}$. Example (34) sums up the properties of $k u u l u a_{A P P}$ utterances.

(34) me jo hättäänny-i-mme

1PL already get.worried-PRET-1PL 
'we were already getting worried'

kon-nei Antti-a koti-ok kuulu-nu

when-NEG.3SG PROP-PART home-ILL KUULUA-PST.PTCP

'because Antti didn't show up at home'

(DMA, Loimaa)

The clause is negative and, as is typical of existential clauses, the subject NP takes the partitive form. The utterance encodes the physical absence of an animate being. In terms of motion, there is non-movement of the subject referent towards the experiencer, in other words the utterance implies a movement that does not take place. The mode of perception is unspecified, but the location where the subject referent should have appeared is overtly expressed (koti-ok 'home-ILL'), and the expectations concerning his arrival are manifest as motivating the emotional reaction from the other participants when he fails to turn up.

In what follows, I explore the interface between negative kuulua ${ }_{P E R C}$ and $k_{u u l u a_{A P P}}$ clauses, aiming to explain why the properties identified in example (34), namely animacy of the subject referent, unspecified mode of perception and the idea of deviating from discursive expectations, are associated with the meaning of appearance in $k u u l u a_{A P P}$ clauses. As the focus is on cases where the difference between the two meanings is subtle, the analysis mostly concerns clauses where the subject is inanimate. The presence of negation and existentiality in kuulua $_{A P P}$ clauses will be dealt with in Section 3.2.2.

It should, first, be noted that the state of affairs described also runs contrary to expectations in negative clauses with kuulua $a_{P R C}$. Negating a perception implies that the perception was expected to take place. ${ }^{22}$ In example (35), the sound of thunder is expected. 
1SG go-PRET there but rumbling-PART NEG.3SG KUULUA-PST.PTCP

'I went there but no rumbling could be heard'

mut(ta) salama-ta $\quad l \ddot{o}-i$

but lightning-PART strike-PRET.3SG

'but the lightning struck'

(DMA, Joutsa)

The discordance with an expected meaning is displayed by the two occurrences of the contrastive conjunction mut(ta) 'but'. The act of 'going' is expected to result in the perception 'hearing the thunder', on the one hand, and seeing (and possibly hearing) lightning is expected to co-occur with the auditory perception of thunder, on the other.

Moreover, even in the case of $k u u l u a_{A P P}$, the fact that one person might be expecting another to appear does not necessarily entail that the appearance of the subject referent is favourable to or wanted by the person that expects. This is illustrated by example (36), where the non-appearance of the subject referent is advantageous to the other two participants.

(36) Ei tämä mökki ole Maunon oma. Mauno ja Maunon Pertta rupesivat

'The cottage is not Mauno's. Mauno and his wife, Pertta, decided' itsestään siihen asumaan keväällä,

'by themselves to live there in the spring,'

kun entis-tä asukas-ta ei ol-lut kuulu-nut

when former-PART inhabitant-PART NEG.3SG AUX-PST.PTCP KUULUA-PST.PTCP 'as the former inhabitant had not shown up' vuote-en. Ehkä se ei tulekaan enää takaisin. year-ILL 
'for a whole year. Maybe he won’t come back anymore.'

(FLC, lehtonen_putkino:p1008)

As I now move on to investigating the occurrences of kuulua ${ }_{P E R C}$ and $k_{u u l u a_{A P P}}$ clauses from the other two perspectives, namely the specificity of mode of perception and animacy, the expectations arising from the context will, in fact, appear different in clauses with kuulua $_{A P P}$ as compared with those with kuuluaPERC.

When it comes to the presence or absence of auditory perception, the line between kuulua $_{P E R C}$ and kuulua $_{A P P}$ is somewhat blurred in certain contexts. As we have seen, kUulua $_{P E R C}$ can appear with a subject NP that does not foreground the sound (see ex. 17 above, where the subject NP refers to 'the displacement of tables'). The meaning of auditory perception is inferred by relying on knowledge of the world (i.e., moving tables makes a sound). However, some kuulua clauses are ambiguous in regard to the presence or absence of auditory perception. ${ }^{23}$ This is the case when the clause refers to a communicative act that may or may not be audible and which, contrary to expectations, does not take place. The first example of this type of context is presented in (37), where the subject NP refers to a potentially audible interactional reaction.

(37) 'Ville!' huusi äiti.

“"Ville!" called the mother.'

Vastaus-ta ei kuulu-nut.

response-PART NEG.3SG KUULUA-PST.PTCP

'No response could be heard.' / 'There came no response.'

Mutta nyt, kun silmät olivat tottuneet hämärään, eroittivat he pojan nurkasta. [...] 
'But now that their eyes had got used to the dark, they could make out the boy in the corner. $[\ldots]$ '

'Vai et sinä vastaa, junkkari, vaikka huudetaan.'

“"So you don't reply, you naughty boy, even if someone calls you."”

(FLC, canth_koyhaa_kansaa:p47)

The clause with kuulua in (37) can be interpreted with reference to the non-appearance of an expected reaction. However, this reaction is a priori audible. Consequently, the two meanings are similarly present. The fact that the experiencer cannot draw on visual perception at the point at which the reaction of the interlocutor is expected to come (as her eyes are not yet used to the dark) could be seen as an argument in favour of interpreting kuulua as referring to auditory perceptibility.

Example (38) presents, for comparison purposes, an extract in which the same noun (vastaus 'response') is used unambiguously to refer to an inaudible communicative act (a letter of response). The reading as $k_{u u l u a_{A P P}}$ thus prevails.

(38) 'Ja vaikka Siljalta pyytäisitte (rahaa)!... Jos hänellä sattuisi olemaan mitä.' [...]

'And what if you asked Silja (for money)!... In case, by chance, she has some."

Vaivoin sai Olli selitetyksi, että on sille kirjoitettu,

'With great effort Olli managed to explain that they had written to her,'

mutta ei vastaus-ta kuulu.

but NEG.3SG response-PART KUULUA.CONNEG

'but no response comes.'

(FLC, lassila_1913_avuttomia:p467) 
Example (39) provides a further example of kuulua utterances with a subject NP referring to a potentially audible reaction (lines 4 and 8 ).

(39) 1 (Äiti kuulustelee pojaltaan aakkosia.)

'(The mother is testing her son's knowledge of the alphabet.)'

2 'No tämän sinä tunnet?' sanoi äiti taas muutamakseen varmana Aukustin puolesta.

“"Well this one you know?" said the mother once again confident of Aukusti.'

3 'A', vastasi Aukusti.

“"A", replied Aukusti.'

$\begin{array}{cclll}\text { 4Kun } & \boldsymbol{e} i & \text { kuulu-nut } & \text { äidi-n } & \text { hyväksymis-tä, } \\ \text { as } & \text { NEG.3SG } & \text { KUULUA-PST.PTCP } & \text { mother-GEN } & \text { approval-PART }\end{array}$

'As he could not hear any approval from the mother / no approval came from the mother'

5 rytkäsi hän hartioitaan ja puristi silmiään yhä lujemmin kiinni ehättäen korjaamaan 'he bent his shoulders, pressed his eyes even more tightly closed and hurried to correct'

6 erehdystään ja sanoi: 'Pehmyt pee.' [...]

'his mistake saying: "Soft p."” [...]

7 Hän odotti äidin voimakkaan käden tunkeutuvan niskaan tavottamaan niskahaituvia.

'He expected the mother's strong hand to make its way to his neck to grab the thin hair.'

8 Ei kuulunut kuitenkaan mitään.

NEG.3SG KUULUA-PST.PTCP however anything

'But nothing could be heard / nothing happened.'

(FLC, pakkala_pi:p824) 
As the first of the mother's expected reactions ('approval') is potentially verbal, two alternative interpretations of the kuulua clause on line 4 emerge: 1) 'mother's approving words could not be heard', 2) 'mother's approval (words or gesture, such as touching) did not take place'. The second clause with kuulua (line 8) also gives rise to a double interpretation: 1) 'nothing could be heard' 2) 'nothing (i.e., no reaction from the mother) took place'. The participant corresponding to the experiencer of the two kuulua clauses keeps his eyes closed during the situation described (see line 5). This excludes the possibility of any visual perception of the mother's gestures and potentially foregrounds the reading as kuulua PERC. However, the mother's reaction, anticipated by the child at this point, is described as tactile (line 7). This can be regarded as prioritizing the interpretation of the second kuulua occurrence as a kuulua $a_{A P P}$.

In addition to clauses with a subject NP referring to a potentially audible reaction, another context likely to produce ambiguity between $k u u l u a_{P E R C}$ and $k u u l u a_{A P P}$ are zero subject clauses. These are illustrated in (40), where a servant (Anni) and the mother (rouva 'mistress') are calling out to a child (Vesa). The utterances presented on lines 3 and 9 contain instances of zero subject.

(40) 1 - Huutaisit nyt kovemmin! käski rouva. Alkoi uusi huuteleminen.

'- You should call him louder! ordered the mistress. The calling started again.'

2 Mutta taas palasi Anni ja ilmotti jo närkästyneen äänellä:

'But once again Anni returned and announced, now irritated:'

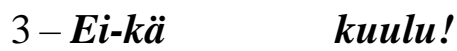

NEG.3SG-CLT KUULUA.CONNEG

'- (The child's response) still cannot be heard!' / '(The child is) still not coming!' 
4 [...] (rouva) mennä väännätteli itse avonaisen akkunan luo ja huuteli:

' [...] (the mistress) herself went laboriously to the open window and called:'

5 -Vesa...! Vesa hoi... Tule syömään [...].

'-Vesa...! Vesa hoy... Come on, time to eat [...].'

6 Mutta turhaan. Lasta ei $\quad$ kuulunut. Odoteltiin.

child-PART NEG.3SG KUULUA-PST.PTCP

'But it was useless. The child did not show up. They kept on waiting.'

7 Ruoka jäähtyi. Jo laski päivä. [...] Annia suututti turha huuteleminen.

'The dinner got cold. The sun was already setting. [...] The useless calling annoyed Anni.’

8 Hän ilmotti kuin suuttuneena:

'She announced with irritation:'

$9-$ No eikä kuulu... Mitä siitä enää huutaakaan!

PTCL NEG.3SG-CLT KUULUA.CONNEG

'- Well still cannot hear (any response) / still not coming... There's no point in calling anymore!'

(FLC, lassila_1911_pojat_asialla:p475)

The ambiguity is produced, on the one hand, by the fact that, the participants who are waiting for the missing child to arrive are addressing him verbally (see lines $1,4-5,7,9$ ) and thus expecting a response perceivable through hearing, the absence of which is coded by the zero subject clauses, and, on the other, by the fact that it is possible to interpret the zero subject clauses as referring to the non-appearance of the child. The kuulua utterance on line 6 is, indeed, unambiguously a kuulua $a_{A P}$ occurrence, since the overt partitive subject refers to an animate being, namely the child. 
Examples (37)-(40) above have shown that the semantics of kuuluaPERC and kuulua $a_{A P P}$ come together in contexts where the kuulua clause describes the absence of an expected reaction that could potentially be verbal. As already mentioned, both meanings of kuulua imply a contrast in regard to discourse expectations. In negative clauses with kuulua PERC, these expectations are based on the causal relation 'state of affairs $\mathbf{p} \rightarrow$ perception of the signal q'.

Clauses with kuulua $_{A P P}$, on the other hand, involve a situation where the state or the action of the experiencer is on some level dependent on or otherwise connected to the potential appearance of the subject referent. The non-appearance is therefore not (only) a perceivable consequence of some state of affairs but essentially an intersubjective act. In many cases, it is conceived as a response to what the experiencer has said or done (see examples 37-40). This accounts for the high degree of animacy of the subject referents of kuulua $_{A P P}$. Only conscious, agentive beings can be included in the intersubjective sharing of experience. In the light of the kuulua clauses in the present data, non-human animate agents are also included in the intersubjective community, as in (41).

(41) Yhdeksi joukoksi liittyneenä härnäsivät he jo kolosta kissaa kepillä.

'United in a group, they were already teasing a cat out of a hole with a stick.' Mutta kun si-tä ei kuulu-nut, kysyi Vesa rutosti: [...]. but as DEM-PART NEG.3SG KUULUA-PST.PTCP 'but as he did not show up, Vesa asked audaciously: [...].'

(FLC, lassila_1911_pojat_asialla:p259)

The subject referent of kuulua $_{A P P}$ is thus in most cases either an animate being who is expected to share the same location with the experiencer at a given time or an abstract 
inanimate entity conceived of as the reaction of another being to something that the experiencer has said or done (e.g., vastaus 'response'). In the rare cases where the subject refers to a concrete inanimate entity (see tables $4 \mathrm{a}$ and $4 \mathrm{~b}$ ), the subject referent is viewed as a constitutive element in the interaction between animate beings. Consider the following examples:

(42) Salmela-lta ei kirje-ttä kuulu-nut. Hanna vakuutti itselleen, PROP-ABL NEG.3SG letter-PART KUULUA-PST.PTCP

'No letter came from Salmela. Hanna assured herself,' ettei hän sitä enää odottanutkaan. 'that she did not expect it anymore.'

(FLC, canth_hanna:p1330)

(43) (Isäntä) oli ruvennut uutta kaivoa valmistamaan, [...]

'(The master of the house) had started preparations for a new well, $[\ldots]$ '

Paikan oli katsonut tunnettu kaivonkatsoja, repaleinen maantienkulkija Heikki

'The place was chosen by a well-known diviner, the ragged vagabond called Heikki,' olisi kyllä tahtonut jonkin matkaa syrjemmälle mutta katsoja ei ollut siihen myöntynyt 'he (the master) would have wanted to place the well a bit further to the side, but the diviner had not agreed -' sanoi, että siinä vesi on paljon syvemmällä.

'he said that the water was much deeper there.'

Ei kuitenkaan häne-n-kään kaivokse-sta-an vet-tä vielä kuulu-nut, [...] NEG.3SG however 3SG-GEN-CLT well-ELA-POSS.3 water-PART yet KUULUA-PST.PTCP 'However, there was no water coming from his well either, $[\ldots]$ ' 
Siitä oli naurua ja puhetta piisannut koko talonväelle, [...].

'This had given rise to amusement and debate among the members of the household, $[\ldots] \cdot$

Mutta vet-tä ei kuulu-nut.

butwater-PART NEG.3SG KUULUA-PST.PTCP

'But no water came.'

(FLC, jarnefelt_isanmaa:p543)

In (42), the subject NP refers to a written communication that one of the participants (Hanna) expects from the other (Salmela). In (43), the subject referent appears to be the focal point of the interaction between the participants. More importantly, the social legitimacy of one of the parties is dependent on the appearance of the subject referent.

In this section, I have analysed the interface between utterances with kuulua $a_{P R C}$ and $k u u l u a_{A P P}$. The aim was to account for the high degree of animacy of the subject NPs in kuulua $_{A P P}$ utterances and to show the difference between the nature of discursive expectations in the case of kuulua $a_{P E R}$ and kuulua $_{A P P}$. In the next section, I will discuss the role of the case marking of the subject argument and the meaning of existentiality in kuulua $a_{A P}$ clauses

\subsubsection{The negative existential meaning and an animate subject referent}

The data from this study indicated a strong link between the meaning of appearance and negation in kuulua $_{A P P}$ constructions. No occurrences in positive clauses were detected, as shown in Table $5 .^{24}$

\begin{tabular}{|c|c|c|c|c|c|c|c|c|}
\hline & \multicolumn{4}{|c|}{ Positive } & \multicolumn{4}{|c|}{ Negative } \\
\hline & NOM & PART & Other & Total & NOM & PART & Other & Total \\
\hline
\end{tabular}




\begin{tabular}{l|llll|rrrr}
\hline DMA & 0 & 0 & 0 & 0 & 1 & 24 & 7 & 32 \\
$\%^{\mathrm{a}}$ & 0 & 0 & 0 & 0 & 3.1 & 75.0 & 21.9 & 100.0 \\
\hline FLC & 0 & 0 & 0 & 0 & 1 & 46 & 11 & 58 \\
$\%^{\mathrm{a}}$ & 0 & 0 & 0 & 0 & 1.7 & 79.3 & 19.0 & 100.0 \\
\hline
\end{tabular}

${ }^{a}$ The proportion of all kuulua $a_{A P P}$ occurrences in the data

Table 5. Subject case marking in kuulua $_{A P P}$ utterances.

As was the case for negative $k u u l u a_{P E R C}$ utterances, the nominative case was also rare in the subject NPs of utterances with $k_{u u l u a_{A P P}}$. There was thus no interplay between the partitive, producing the meaning of absolute non-existence, and the nominative, expressing relative non-presence. Nevertheless, most utterances with kuulua $_{A P P}$ did not produce the meaning of absolute non-existence, as the majority of subject NPs in partitive form referred to specific entities. There were 26 specific and 5 non-specific entities in the DMA, and 40 specific and 17 non-specific entities in the FLC. In general, the very existence of the specific animate being was not at stake but merely its presence at a given location. Examples (44) (already analysed in 37) and (45) display the contrast between the specific and non-specific readings of the partitive subject NP in $k u u l u a_{A P P}$ utterances.

(44) 1 'Ville!' huusi äiti.

"Ville!" called the mother.'

2 Vastaus-ta ei kuulu-nut.

response-PART NEG.3SG KUULUA-PST.PTCP

'No response could be heard.' / 'There came no response.'

3 Mutta nyt, kun silmät olivat tottuneet hämärään, eroittivat he pojan nurkasta. [...]

'But now that their eyes had got used to the dark, they could make out the boy in the corner. $[\ldots]^{\prime}$

4 'Vai et sinä vastaa, junkkari, vaikka huudetaan.'

“"So you don’t reply, you naughty boy, even if someone calls you.",

(FLC, canth_koyhaa_kansaa:p47) 
(45)

Mikä lie-ne-e tul-lut Rissala-n isännä-lle,

Q AUX-POT-3SG come-PST.PTCP PROP-GEN master-ALL

'What could have happened to Mr Rissala,'

kun si-tä ei kuulu-nut takaisin kaupungi-sta.

CONJ 3SG-PART NEG.3SG KUULUA-PST.PTCP back town-ELA

'as he did not return from the town.'

Toissa päivänä meni, eikä pitänyt viipyä kuin muutaman tunnin.

'He went there the day before yesterday, and he was not supposed to stay for more than a few hours.'

(FLC, canth_hanna:p365)

In (44), the absolute existential meaning emerges. The description of the situation (line 3) and the mother's reaction to the absence of response (line 4) show that no response whatsoever has been given. In (45), however, it is not the actual existence of the subject referent (Rissalan isäntä 'Mr Rissala') that is at issue but his non-(re)appearance at the expected location.

In view of the relatively high number of co-occurrences of specific reference and the partitive form in the subject NPs of utterances with $k u u l u a_{A P P}$ in the data, it can be assumed that the partitive case is not just triggered by the negation, but also forms an important part of the kuulua $_{A P P}$ construction. Rather than coding the existentiality, the partitive case is one of the units in the construction that convey the particular meaning of non-appearance in the expected location. The grammatical status and the possible evolution of $k u u l u a_{A P P}$ are discussed in the following section.

\section{DISCUSSION AND CONCLUSION}


In this paper, I have examined the polysemy of the verb kuulua 'to be perceptible (through audition/unspecified sensory input)' in the light of the degree of animacy of the participants involved and the existential status of the predication. The focus was on the syntactic and semantic differences and the overlaps between the two constructions, that is, those including kuulua as a verb of auditory perceptibility and those where kuulua codes the non-appearance of an entity in a given location.

The semantic core of the verb kuulua involves the meaning of motion of an entity towards the perceiver. Constructions with kuulua $a_{P E R}$ and $k u u l u a_{A P P}$ differ in terms of the type of motion and the degree of animacy of the moving entity. ${ }^{25}$

In kuulua ${ }_{P E R C}$ utterances, the meaning of perceptibility is conceived of as a potential fictive motion of a sound towards the experiencer. Accordingly, in most cases, the subject of kUulua $a_{P E R C}$ constructions refers to the perceptible sound. When the subject referent is some other inanimate abstract or concrete entity, the clause is likely to be understood as referring metonymically to the sound emitted by the entity (see Panther \& Thornburg 2003:225-226; Huumo 2010:91).

The sounds of individual animate beings are understood as at least having the potential to be meaningful, as they indicate the mental state or communicative aim of the subject referent. This explains why the metonymic figure observable in kuulua ${ }_{P E R C}$ utterances with an inanimate subject referent was not found in the data in utterances where the subject referred to an animate being. ${ }^{26}$ In this construction, an animate being cannot be reduced to its sound, because perceiving the sound intrinsically involves considering the producer of the sound not only as the source of the stimulus but as a participant in the interaction, whose presence and intentions demand to be interpreted. ${ }^{27}$ The data suggest that in the rare cases where an animate subject is involved in a kuuluaPERC construction the subject referent displays a low degree of 
individuality and individual control over the situation (e.g., orkesteri 'orchestre' in ex. 30), in other words, the referent ranks relatively low among animate entities on the animacy scale.

Accordingly, in kuulua $a_{A P P}$ constructions, it is not the sound that is at issue but the (lack of) fictive or physical motion of another individual engaged in a relationship of cognitive coordination. In this sense, the meaning of (im)perceptibility can involve not only the (in)ability to be perceived but also the potential of being interpreted and understood in the context of the intersubjective construal of meaning.

The fact that the specialized function assumed by the kuulua $a_{A P P}$ construction emerges in non-affirmative, mainly negative contexts can also be viewed in the light of the intersubjective dimension of meaning construal. Indeed, Verhagen (2005) argued that negation is, specifically, a type of linguistic construction that operates on an intersubjective level (ibid. pp. 42-43). In kuulua $a_{A P P}$ utterances, the relationship between the subject referent and the experiencer is viewed in the context of an interaction entailing communicational expectations around the subsequent verbal or behavioural moves. The implied fictive or physical movement of the subject referent is thus also a move on the intersubjective level. In discourse, interactional expectations become manifest when something goes against them. The negative expression opens another mental space in the communicative situation (Verhagen 2005:29-30). The negative kuulua $_{A P P}$ construction is the linguistic realization of an absence, which implies the unrealized possibility of an interactional move (see Nahajec 2014).

While the evolution of the different meanings of kuulua was not the focus of this study, we may assume that kuulua $_{A P P}$ is the result of a grammaticalization process from a more specific lexical meaning ('being perceptible through audition') to one that is more general ('being (im)perceptible through unspecified sensory input'). As a result of the semantic extension, not only has the mode of perception expressed by the verb kuulua become 
unspecified, but the construction carrying the new meaning has also lost the alternation between nominative and partitive subjects, and its use has become limited to negative contexts involving mostly an animate subject. The path from the meaning of kuulua PERC to that of Kuulua $_{A P P}$ could have passed through the so-called bridging contexts, such as those presented in examples (37)-(40) in Section 3.2.1, where the two meanings intersect (see Evans \& Wilkins 2000:549-550). In these cases, the meaning of auditory perceptibility occurs in a context where the perceptible sound is viewed as an expected communicative movement. Over time, the absence of an auditory response could have been conceived of as the absence of any perceptible communicative movement towards the experiencer.

The fixed partitive form and the restriction to non-affirmative (mainly negative) contexts indicate the specialized functions of $k u u l u a_{A P P}$ utterances. These latter can be considered as a case of formal idioms involving partially fixed lexical units (see Fillmore, Kay \& O’Connor 1988:505; Michaelis 2017; see also Huumo 2010:91-92). The kuulua $a_{A P}$ construction is a lexico-grammatical syntactic pattern that moves the semantics of perceptibility away from the vertical dimension of objective meaning construal to the horizontal link between SoCs.

The grammaticalization path from 'being audible' to 'being (im)perceptible through unspecified sensory input' does not seem to be an areally or genetically widespread phenomenon. For example, the verbs of auditory perceptibility in Swedish (höras) and in Estonian (kuulduma, kostma $)^{28}$ have not undergone such evolution, while they are relatively similar to kuulua by their form and their semantics. On the other hand, the Carelian verb kuuluo is used to encode absence in negative sentences (Koissa poikua vuotetah; ei kuulu 'The boy is awaited at home; [he] does not appear', KKS 2009, s. v. kuuluo).

Among perception verbs, those coding perceptibility have so far received the least attention. This may be due to the internal heterogeneity characterizing this category of verbs 
as well as the somewhat fuzzy nature of the borders delimiting it. The classification used by Viberg (2015) for presenting the system of perception verbs in Swedish indicates points of contact between perceptibility verbs, sensory copulas (e.g., 'sound like') and sensory verbs (e.g., 'shine'). The present analysis of kuulua constructions, moreover, suggests that perceptibility is a complex semantic category that lies at the intersection of meanings of perception, modality, existentiality and apparition. Finally, it suggests that the perception of stimuli coming from an inanimate source is not conceptualized in the same way as the perception of stimuli produced by animate, individual beings.

\section{ACKNOWLEDGEMENTS}

I would like to thank the three anonymous NJL reviewers for their valuable and constructive comments. I am also grateful to Outi Duvallon for her helpful suggestions on an earlier version of this paper.

\section{DATA SOURCES}

DMA, Digital Morphology Archives. Department of Finnish, Finno-Ugrian and Scandinavian Studies at the University of Helsinki and CSC - IT Center for Science. Http://urn.fi/urn:nbn:fi:lb-201403261.

FLC, Finnish Literary Classics. Institute for the Languages of Finland. Http://kaino.kotus.fi/korpus/klassikot/meta/klassikot_coll_rdf.xml.

\section{REFERENCES}


Aikhenvald, Alexandra Y. \& Anne Storch (eds.). 2013a. Perception and Cognition in Language and Culture. Leiden: Brill.

Aikhenvald, Alexandra Y. \& Anne Storch. 2013b. Linguistic expression of perception and cognition: A typological glimpse. In Alexandra Y. Aikhenvald \& Anne Storch (eds.), Perception and Cognition in Language and Culture, 1-46. Leiden: Brill.

Anscombre, Jean-Claude \& Oswald Ducrot. 1997. L'argumentation dans la langue. 3rd edn. Liège: Mardaga.

Boye, Kasper. 2010. Reference and clausal perception-verb complements. Linguistics 48, $391-430$.

Caballero, Rosario \& Carita Paradis. 2015. Making sense of sensory perceptions across languages and cultures. Functions of Language 22, 1-19.

Creissels, Denis. 2014. Existential predication in typological perspective. Ms. (Paper presented at the $46^{\text {th }}$ Annual Meeting of the Societas Linguistica Europaea, Split, 18-21 September 2013.) Http://www.deniscreissels.fr/public/Creissels-Exist.Pred.pdf (accessed June 27, 2017).

Dahl, Östen. 2008. Animacy and egophoricity: Grammar, ontology and phylogeny. Lingua $118,141-150$.

Dahl, Östen \& Kari Fraurud. 1996. Animacy in grammar and discourse. In Thorstein Fretheim \& Jeanette K. Gundel (eds.), Reference and Referent Accessibility, 47-64. Amsterdam: Benjamins.

DMA Research project. 2008-2010. University of Helsinki, Research portal Tuhat. Https://tuhat.helsinki.fi/portal/en/projects/digital-morphology-(ab85fb5a-7678-49c6bba7-0067e486913a).html (accessed March 10, 2017).

Dik, Simon \& Kees Hengeveld. 1991. The hierarchical structure of the clause and the typology of perception-verb complements. Linguistics 29, 231-259. 
Dowty, David. 1991. Thematic proto-roles and argument selection. Language 67, 547-619.

Duranti, Alessandro. 2010. Husserl, intersubjectivity and anthropology. Anthropological Theory 10, 1-20.

Duvallon, Outi. 2009. Exprimer son identité par des moyens grammaticaux: la mise en scène du 'moi'. Cahiers de la Nouvelle Europe: Langues et identités finlandaises, 67-87.

Duvallon, Outi. Forthcoming. Pluralité indéfinie et individuation de la référence : L'exemple des quantifieurs moni et monta 'plusieurs' en finnois. In Christine Bonnot, Outi Duvallon \& Hélène de Penanros (eds.), Individuation et référence nominale à travers les langues.

Enghels, Renata. 2007. Les modalités de perception visuelle et auditive. Tübingen: Max Niemeyer Verlag.

Evans, Nicholas \& David Wilkins. 2000. In the mind's ear: The semantic extensions of perception verbs in Australian languages. Language 76, 546-592.

Fillmore, Charles J., Paul Kay \& Mary Catherine O'Connor. 1988. Regularity and idiomacity in grammatical constructions: The case of let alone. Language 64, 501-538.

Fraurud, Kari. 1996. Cognitive ontology and NP form. In Thorstein Fretheim \& Jeanette K. Gundel (eds.), Reference and Referent Accessibility, 65-88. Amsterdam: Benjamins.

Hakulinen, Lauri. 1979. Suomen kielen rakenne ja kehitys [The structure and evolution of Finnish language]. 4th edn. Helsinki: Otava.

Huumo, Tuomas. 2003. Incremental existence: The world according to the Finnish existential sentence. Linguistics 41, 461-493.

Huumo, Tuomas. 2010. Is perception a directional relationship? On directionality and its motivation in Finnish expressions of sensory perception. Linguistics 48, 49-97. 
Huumo, Tuomas \& Marja-Liisa Helasvuo. 2015. On the subject of subject in Finnish. In Marja-Liisa Helasvuo \& Tuomas Huumo (eds.), Subjects in Constructions: Canonical and Non-Canonical, 13-41. Amsterdam: Benjamins.

Huumo, Tuomas \& Liina Lindström. 2014. Partitives across constructions: On the range of uses of the Finnish and Estonian "partitive subjects". In Silvia Luraghi \& Tuomas Huumo (eds.), Partitive Cases and Related Categories, 153-175. Berlin: Walter de Gruyter.

Jakobi, Angelika \& El-Shafie El-Guzuuli. 2013. Perception verbs and their semantics in Dongolawi (Nile Nubian). In Alexandra Y. Aikhenvald \& Anne Storch (eds.), Perception and Cognition in Language and Culture, 193-215. Leiden: Brill.

Janhunen, Juha. 2014. On the "zero consonant" phoneme in modern standard Finnish: Toward a coherent paradigmatic interpretation. In Nobufumi Inaba, Jorma Luutonen, Arja Hamari \& Elina Ahola (eds.), Juuret marin murteissa, latvus yltää Uraliin, 129-140. Helsinki: Suomalais-Ugrilaisen Seuran Toimituksia - Mémoires de la Société FinnoOugrienne 270. Http://www.sgr.fi/sust/sust270/13_janhunen.pdf (accessed April 27, 2017).

Jääskeläinen, Anni. 2013. Todisteena äänen kuva: Suomen kielen imitatiivikonstruktiot [Imitations of sounds as evidence: The constructions of imitatives in the Finnish language]. Ph.D. dissertation. Department of Finnish, Finno-Ugrian and Scandinavian Studies, University of Helsinki. Http://urn.fi/URN:ISBN:978-952-10-8860-5 (accessed June 27, 2017).

Häkkinen, Kaisa. 1987. Nykysuomen sanakirja: Etymologinen sanakirja [Dictionary of Modern Finnish: Etymological dictionary]. Porvoo: WSOY. 
Kettunen, Lauri. 1940. Suomen murteet III A. Murrekartasto [The Finnish dialects III A. Dialect map]. Helsinki: Finnish Literature Society. Http://kettunen.fnhost.org/html/kett119.html (accessed April 27, 2017).

Kittilä, Seppo, Katja Västi \& Jussi Ylikoski. 2011. Introduction to case, animacy and semantic roles. In Seppo Kittilä, Katja Västi \& Jussi Ylikoski (eds.), Case, Animacy and Semantic Roles, 1-26. Amsterdam: Benjamins.

KKS $=$ Karjalan kielen sanakirja (The dictionnary of Carelian language). 2009. Helsinki: Institute for the languages of Finland. Http://kaino.kotus.fi/cgi-bin/kks/kks_etusivu.cgi (accessed June 28, 2017).

Kuno, Susumu \& Etsuko Kaburaki. 1977. Empathy and syntax. Linguistic Inquiry 8, 627672.

Langacker, Ronald W. 1987. Foundations of Cognitive Grammar, Vol.1: Theoretical Prerequisites. Stanford, CA: Stanford University Press.

Langacker, Ronald W. 1991. Foundations of Cognitive Grammar, Vol. 2: Descriptive Application. Stanford, CA: Stanford University Press.

Levin, Beth. 1993. English Verb Classes and Alternations: A Preliminary Investigation. Chicago: The University of Chicago Press.

Lockwood, Hunter T. \& Monica Macaulay. 2012. Prominence hierarchies. Language and Linguistics Compass 6/7, 431-446.

Michaelis, Laura A. 2017. Meanings of constructions. Oxford Research Encyclopedia of Linguistics.

Http://linguistics.oxfordre.com/view/10.1093/acrefore/9780199384655.001.0001/acrefo re-9780199384655-e-309 (accessed December, 11, 2017).

Nahajec, Lisa. 2014. Negation, expectation and characterization: Analysing the role of negation in character construction in To Kill a Mockingbird (Lee 1960) and Stark 
(Eltoon 1989). In Siobhan Chapman \& Billy Clark (eds.), Pragmatic Literary Stylistics, 111-131. Houndmills, Basingstoke: Palgrave Macmillan.

Narrog, Heiko. 2016. Three types of subjectivity, three types of intersubjectivity, their dynamicization and a synthesis. In Daniel Olmen, Hubert Cuyckens \& Lobke Ghesquière (eds.), Aspects of Grammaticalization: (Inter)Subjectification and Directionality, 19-46. Berlin: Walter de Gruyter.

NS = Nykysuomen sanakirja [Dictionary of Modern Finnish]. 1951-1961. Porvoo: WSOY. Nykänen, Elise \& Aino Koivisto. 2016. Introduction: Approaches to fictional dialogue. Literary Linguistics 5. Http://dx.doi.org/10.15462/ijll.v5i2.56 (accessed March 10, 2017).

Ono, Haruhiko. 2004. On the semantic difference between the do-form and the doing-form in perception verb complements: from the viewpoint of 'perception' and 'cognition'. Journal of Pragmatics 36, 407-439.

Palmer, F. R. 2001. Mood and Modality. Cambridge: Cambridge University Press.

Panther, Klaus-Uwe \& Linda Thornburg. 2003. The effect for cause metonymy in English grammar. In Antonio Barcelona (ed.), Metaphor and Metonymy in the Crossroads: A Cognitive Perspective, 215-231. Berlin: Mouton de Gruyter.

Partee, Barbara H. \& Vladimir Borschev. 2004. The semantics of Russian genitive of negation: The nature and role of perspectival structure. In Robert B. Young (ed.), Proceedings of the $14^{\text {th }}$ Semantics and Linguistic Theory Conference, May 14-16, 2004, $212-234$.

Http://journals.linguisticsociety.org/proceedings/index.php/SALT/article/view/2908 (accessed March 17, 2017). 
Schneider-Blum, Gertrud \& Gerrit J. Dimmendaal. 2013. Excite your senses: Glances into the field of perception and cognition in Tima. In Alexandra Y. Aikhenvald \& Anne Storch (eds.), Perception and Cognition in Language and Culture, 217-249. Leiden: Brill.

Silverstein, Michael. 1976. Hierarchy of features and ergativity. In Robert M.W. Dixon (ed.), Grammatical Categories in Australian Languages, 112-171. Canberra: Australian Institute of Aboriginal Studies.

Talmy, Leonard. 2000. Toward a Cognitive Semantics, Volume I: Concept Structuring Systems. Cambridge: MIT Press.

Tottie, Gunnel \& Anja Neukom-Hermann. 2010. Quantifier-negation interaction in English: A corpus linguistic study of all...not constructions. In Laurence R. Horn (ed.), The Expression of Negation, 149-185. Berlin: Walter de Gruyter.

Van Valin, Jr., Robert D. \& David P. Wilkins. 1996. The case for 'Effector': Case roles, agents and agency revisited. In Masayoshi Shibatani \& Sandra A. Thompson (eds.), Grammatical Constructions: Their Form and Meaning, 289-322. Oxford: Oxford University Press.

Verhagen, Ariel. 2005. Constructions of Intersubjectivity: Discourse, Syntax and Cognition. Oxford: Oxford University Press.

Verhagen, Ariel. 2008. Intersubjectivity and the architecture of the language system. In Jordan Zlatev, Timothy P. Racine, Chris Sinha \& Esa Itkonen (eds.), The Shared Mind: Perspectives on Intersubjectivity, 307-331. Amsterdam: Benjamins.

Verhoeven, Elisabeth. 2007. Experiential Constructions in Yucatec Maya: A typologically based analysis of a functional domain in a Mayan language. Amsterdam: Benjamins.

Verhoeven, Elisabeth. 2014. Thematic prominence and animacy asymmetries: Evidence from a cross-linguistic production study. Lingua 143, 129-161. 
Veselinova, Ljuba. 2013. Negative existentials: A cross-linguistic study. Italian Journal of Linguistics 25, 107-145.

Viberg, Åke. 1984. The verbs of perception: A typological study. Linguistics 21, 123-163.

Viberg, Åke. 2008. Swedish verbs of perception from a typological and contrastive perspective. In Maria de los Ángeles Gómez González, J. Lachlan Mackenzie \& Elsa M. González Álvarez (eds.), Languages and Cultures in Contrast and Comparison, 123-172. Amsterdam: Benjamins.

Viberg, Åke. 2015. Sensation, perception and cognition: Swedish in a typological-contrastive perspective. Functions of Language 22, 96-131.

VISK = Auli Hakulinen, Maria Vilkuna, Riitta Korhonen, Vesa Koivisto, Tarja Riitta Heinonen \& Irja Alho. 2004. Iso suomen kielioppi (verkkoversio) [The comprehensive grammar of Finnish (online version)]. Helsinki: Finnish Literature Society. http://scripta.kotus.fi/visk/etusivu.php (accessed December 12, 2017).

Von Waldenfels, Ruprecht. 2012. Finnish antaa and Russian davat' 'to give' as causatives: A contrastive analysis. In Jaakko Leino \& Ruprecht von Waldenfels (eds.), Analytical Causatives: From 'give' and 'come to 'let' and 'make', 187-220. München: Lincom Europa.

Whitt, Richard J. 2009. Auditory evidentiality in English and German: The case of perception verbs. Lingua 119, 1083-1095.

Yamamoto, Mutsumi 1999: Animacy and Reference: A Cognitive Approach to Corpus Linguistics. Amsterdam: Benjamins.

Zlatev, Jordan, Timothy P. Racine, Chris Sinha \& Esa Itkonen. 2008. Intersubjectivity: What makes us human? In Jordan Zlatev, Timothy P. Racine, Chris Sinha \& Esa Itkonen (eds.), The Shared Mind: Perspectives on Intersubjectivity, 1-14. Amsterdam: Benjamins. 


\section{NOTES}

${ }^{1}$ Abbreviations used in the interlinear morphemic translations: ABL - ablative, ADE - adessive, ALL - allative, AUX - auxiliary, CLT - clitic, COMP - complementizer, CONJ - conjunction, CONNEG - connegative, DEM - demonstrative, DET - determiner, ELA - elative, GEN - genitive, ILL - illative, IMP - imperative, INF - infinitive, LAT - lative, NEG - negation, NOM nominative, ONOM - onomatopoeia, PART - partitive, PL - plural, POSS - possessive, POT potential, PRET - preterite, PROP - proper noun, PRS - present, PST - past, PTCL - particle, PTCP - participle, Q - question marker, REL - relative, SG - singular (see Leipzig Glossing Rules: http://www.eva.mpg.de/lingua/resources/glossing-rules.php)

${ }^{2}$ Kuulua is a polysemous verb whose functions extend beyond the meaning of perception. If the uses of kuulua in contexts not involving perception are taken into consideration, the clause in (1b) is in fact acceptable with the meaning 'The child belongs to the neighbours' (see Section 1.3).

${ }^{3}$ Finnish existential clauses can be further divided into subcategories according to the presence or absence of a locative or temporal adverbial and the degree of impersonality of the construction (see VISK 2004:§891; Jääskeläinen 2013:159-164). I will not make this distinction in the present study.

${ }^{4}$ For a more exhaustive presentation of the Finnish existential constructions, see Huumo (2003) and Huumo \& Lindström (2014). For a critical view on the subject status of the NP in existential clauses, see Huumo \& Helasvuo (2015).

${ }^{5}$ The dialect data was collected by linguistically trained fieldworkers in 160 parishes from the 1960s to the 1990s. It was originally stored on paper file cards but has now been digitized (see DMA Research project 2008-2010). 
${ }^{6}$ For the difference between 'pure and cognitive perception' or 'direct and indirect perception', see also Ono (2004), Enghels (2007:Chapter 2.2).

${ }^{7}$ For the evidential use of source-based perception verbs, see Whitt (2009:1085).

${ }^{8}$ There are, nevertheless, constructions in which animacy does not play a role in coding the agent (see, e.g., Kittilä et al. 2011:12).

${ }^{9}$ For the relationship between intersubjectivity, interaction and mutual understanding, see Duranti (2010).

${ }^{10}$ Profiling is indicated in the figures by full line.

${ }^{11}$ Verhagen (2005:18) developed his theory of intersubjectivity on the basis of Anscombre's \& Ducrot's works on argumentation and polyphony (p. ex. 1997:178) and Langacker's (1987:487-488) model of the construal relationship between the speaker and the conceived situation. Verhagen's construal configuration is more complex than Langacker's, in that it intrinsically includes another subject of conceptualization, along with the conceptualizer who is responsible for the utterance (cf. Anscombre's \& Ducrot's locuteur and énonciateur). The subject of conceptualization level corresponds, in Langacker's (1987:126, 1990: 9) terms, to the Ground, which contains knowledge of the communicative event, the participants and the circumstances involved. For a discussion on the particularities of Verhagen's theory, by comparison to other views on linguistic intersubjectivity, see Narrog (2016).

${ }^{12}$ In Viberg (1984), the third type was illustrated by verbs that code the impression evoked by the perception (e.g., Peter sounded happy). This type of use is also possible for the basic perception verbs in Finnish (see ex. 6 above). In the present study, however, these have been excluded from the data in order to concentrate on verbs coding immediate perception (see Huumo 2010:53). The term perceptibility comes from Huumo (ibid., see also Viberg 2015). 
${ }^{13}$ From a cross-linguistic perspective, it should be noted that, in some languages, the expertum, that is, the experiential situation itself, may take the subject or direct object function (see Verhoeven 2007:78-79).

${ }^{14}$ minä kuulun is acceptable when kuulua is used to express belonging ('I belong [to sth]', see note 2).

${ }^{15}$ Aikhenvald \& Storch (2013b:19) illustrated the interplay between the meaning of perception and the semantics of the construction by discussing the effect of the imperative on the interpretation of perception verbs.

${ }^{16}$ Viberg (1984, 2015:107-109) considered visual perception as being universally the primary and most basic sensory experience (see also, e.g., Huumo 2010). Evans \& Wilkins's (2000) study involving a large set of Australian languages supported the claimed tendency of semantic change from vision to the other senses within the domain of perception verbs. However, this hierarchical view of the human senses was criticized by Aikhenvald \& Storch (2013a).

${ }^{17}$ The morpho-syntactic characteristics of Finnish existential sentences have been briefly listed in the Introduction. I will develop their analysis in Sections 3.1.2 and 3.2.2.

${ }^{18}$ kuulua $_{P E R C}$ can also foreground the quality of the emission. In this case, the clause may lack an overt subject, as in (i):

(i) ei tahok kuulu-o, oekeeh hyvästi NEG.3SG will.CONNEG KUULUA-INF very well ('It won't sound very well' >) 'I can't hear very well'

(DMA, Kajaani)

${ }^{19}$ Both direct and indirect interrogative uses are taken into account. The distinction between the two is not always possible to make, at least when based on the transcription (see ex. 22). 
${ }^{20}-s e[k / n]$ is a dialectal variant of the third person possessive suffix used in some of the Eastern dialects of Finnish (see Kettunen 1940, map 119). The final $-r$ results from the consonant assimilation that takes place at word boundary position when the preceding item contains a final latent consonant, in this case $k / n$ (see Janhunen 2014:134-135).

${ }^{21}$ Two of these animate subjects occured in constructions that can be regarded as intermediate between the uses of kuulua as a verb of perception and as a verb of appearance (on the overlap between the two constructions, see Section 3.2.1).

${ }^{22}$ This is a specific manifestation of the more general fact that negative sentences occur in the presence of expectations arising from the context (see, e.g., the discussion in Tottie \& Neukom-Hermann 2010:175-177). This property of negation will be discussed in terms of intersubjectivity in Section 4.

${ }^{23}$ Ambiguous cases, where both meanings of auditory perception and imperceptibility through an unspecified mode of perception are present, were counted among the occurrences of kUULUAPERC.

${ }^{24}$ Positive direct and indirect interrogative clauses may, however, be a potential context in which the meaning of appearance occurs. The following utterance, found on the internet, sounds plausible to a native ear. The speaker has sent a dress by postal delivery, and, in this utterance, she is quoting herself when she makes contact with the recipient afterwards.

(i) No, kysäis-i-n sitten, että on-ko si-tä kuulu-nut si-tä kolttu-a. PTCL ask-PRET-1SG PTCL COMP AUX.3SG-Q DEM-PART KUULUA-PST.PTCP DET-PART dress-PART

'So I asked if the dress had appeared.'

(Internet)

${ }^{25}$ The same type of abstract meaning is likely to be found in the uses of kuulua where the meaning of perception as such is not involved. For example, when kuulua encodes the 
meaning 'to belong to something or someone' (see Section 1.3, examples 7-8), the subject referent's relationship with the larger category or the possessor can be conceived of as fictive motion towards them. This is reflected in the case marking within the construction since the complement referring to the target of belonging is marked with the illative or allative case, which denote the endpoint of a movement ('into'). As for the position of the conceptualizer, the situation is viewed not only as being perceived by them but principally as resulting from their mental activity allowing them to make the connection between the subject referent and the target of belonging.

${ }^{26}$ Panther \& Thornburg (2003:225-226) analyzed the metonymy PERCEPTUAL EVENT FOR ITS CAUSE in question-answer pairs. Interestingly, in this context, animate causers of noise can appear as participants of the metonymic link: - What's that noise? - A squirrel / A burglar.

${ }^{27}$ For an overview of sensory meanings and human communication, see Caballero \& Paradis (2015).

${ }^{28}$ Virve Vihman, personal communication, May 3, 2017. 